\title{
EFFECTIVE ENTREPRENEURSHIP EDUCATION THROUGH TEACHING CASE
}

\author{
Kshitij Shinghal $^{1}$, Amit Saxena ${ }^{2}$ \\ ${ }^{1}$ Associate Professor, ${ }^{2}$ Assistant Professor, \\ Deptt. of E\& C Engg, Moradabad Institute of Technology, Moradabad, India
}

\begin{abstract}
Developing an Entrepreneurial mindset with the help of teaching case is very effective. This type of learning involves the students and make them participate in learning process rather than absorbing Knowledge in case of conventional teaching. This paper explains the methodology involved in developing such a case. The paper also presents a sample case so that the user are able to grasp the idea of selecting suitable cases for experiential learning.
\end{abstract}

KEYWORDS: Teaching case, caselet, Experiential learning.

\section{Introduction}

Teaching through case is very powerful method of experiential learning. In this teachers are not only the transmitters and students are not passive receptors of knowledge. But they learn the concepts by actually participating in the activity. A sample case for teaching key skills of Entrepreneurship to students is given. There was a young man named Rahul. He was standing in the market. While an elderly person passed him talking with his colleague. The Elderly person told his colleague that there are ample business opportunities lurking everywhere, one must have initiative and enterprise. One only need a good vision and sight to identify the opportunity. Passing by he saw a dead mouse and told his colleague that even if one has no money but will to take initiative, one can just pick up the dead mouse and start a business. To this his colleague laughed at idea of using dead mouse as capital. However Rahul overheard all this and though he felt that it was a weird idea but having faith on elderly persons words he picked up the dead mouse. He kept wondering what he can do with it, who would buy a dead mouse from him? While he was pondering a rich merchant crossed him carrying in his hands his pet cat. The cat jumped from his hands seeing the dead mouse in the hands of Rahul. On realizing what attracted the cat, the rich Merchant asked Rahul to sell his mouse to him and paid him one coin for it. Rahul was rejoiced he had earned his first coin. He remembered what elderly person has said "One must have initiative and Enterprise". He thought "I must find out. If there is a demand for something and then arrange to supply it". After making a survey he purchased jaggery of one paisa and filled a pot of water and went to the outskirts of the city. He waited there for the flower gatherers to return from work. In late afternoon when flower gatherers were returning from their work they began to feel hot and thirsty. There was no water source between the jungle to the city. Soon they saw Rahul who offered them cool water and Jaggery, in return to which they gave him a bunch of flowers. By the time his Jaggery finished he had a good heap of flowers. He took those flowers to the village temple, where flower were quickly sold. Rahul earned 10 coins selling the flowers. Now Rahul has learned the art of finding opportunities and converting them to profitable enterprise by taking initiatives. Soon with his hardwork, newly developed skills Rahul become one of the richest person of the city. 
- What are the key concepts learned from the strong.

- Was Rahul having required skill set from the beginning of the story.

- What were the characteristics that made Rahul successful.

- Did the mindset of Rahul changed at the end of story.

- Do one need large investment to start on Enterprise?

\section{Methodology}

While designing or selecting a case, an educator must consider following questions

(1) What is the main objective of selecting the case.

(2) What is the main theory or concept you are going to teach.

(3) Is case interesting enough to grab attentions of students.

(4) How will students respond to the case.

(5) Is the case challenging, interesting to invoke thought process of students.

(6) Will the case serve its purpose and will impart useful teaching and learning concept effectively to students.

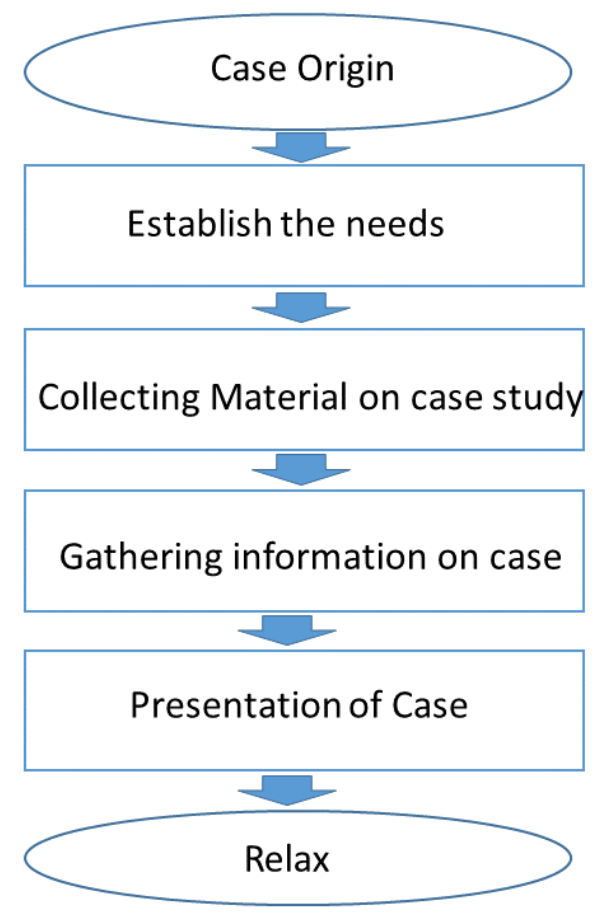

Figure 1: Flowchart for case study

\section{Conclusion}

A good teaching case should be able to demonstrate the concept which teacher is willing to teach the students. It should be interesting with sufficient twists and turns to hook the students. It should be able to create desired effect by creating enough dynamic tension to produce and trigger thought process of the students finally it should be able to demonstrate the concept which teacher wants students to learn. 


\section{Acknowledgement}

We owe our sincere feelings of gratitude to MIT Group of Institutions, Moradabad. We are also thankful to mentors for their support, guidance and suggestions, which helped us a lot to write the paper.

\section{References}

[1]. Sijde, Peter \& Ridder, Annemarie \& Blaauw, Gerben \& Diensberg, Christoph. (2008). Teaching Entrepreneurship: Cases for Education and Training. 10.1007/978-3-7908-2038-6.

[2]. Arasti, Zahra \& Corresponding, \& Falavarjani, Mansoreh \& Imanipour, Narges. (2012). A Study of Teaching Methods in Entrepreneurship Education for Graduate Students. Higher Education Studies. 2. 10.5539/hes.v2n1p2.

[3]. Zahra Arasti, Mansoreh Kiani Falavarjani, Narges Imanipour, "A Study of Teaching Methods in Entrepreneurship Education for Graduate Students", Higher Education Studies, Vol. 2, No. 1; pp 2-9, March 2012. doi:10.5539/hes.v2n1p2

[4]. Esmi, K., Marzoughi, R., \& Torkzadeh, J. (2015). Teaching learning methods of an entrepreneurship curriculum. Journal of advances in medical education \& professionalism, 3(4), 172-177.

[5]. B. Baruah and A. Ward, "Enhancing intrapreneurial skills of students through entrepreneurship education," 2014 Information Technology Based Higher Education and Training (ITHET), York, 2014, pp. 1-6.

[6]. Astri Ghina, "Effectiveness of Entrepreneurship Education in Higher Education Institutions", $5^{\text {th }}$ Indonesia International Conference on Innovation, Entrepreneurship and Small Business (IICIES 2013), doi: 10.1016/j.sbspro.2014.02.440.

[7]. Kshitij Shinghal, Amit Saxena, "Developing Entrepreneurial Mindset in Engineers", International Journal of Scientific Research and Management Studies (IJSRMS), Volume 4 Issue 2, pg: 50-55, Sept. 2017.

Kshitij Shinghal has 18 Years of experience in the field of Academic and is actively involved in research \& development activities. He obtained his Doctorate degree from Shobhit University Meerut in 2013, Masters degree (Digital Communication) in 2006 from UPTU, Lucknow. He started his career from MIT, Moradabad. Presently he is working as an Associate Professor, Deptt of E\&C Engg., at MIT Moradabad. He has published number of papers in national journals, conferences and seminars. He has guided two Masters, more than sixty students of B. Tech, and guiding three Ph.D. \& M. Tech. theses. He is an active Member of Various Professional Societies such as ISTE, IACSIT, IAENG etc.

Amit Saxena has 12 Years of experience in the field of Academic. He obtained his Bachelor's degree in Electronics \& Communication Engineering from I.E.T., Rohilkhand University, Bareilly and Masters degree (VLSI Design) in 2009 from UPTU, Lucknow. He started his career from MIT, Moradabad. Presently he is working as an Assistant Professor, Deptt of E\&C Engg., at MIT Moradabad. He has published number of papers in international \& national journals, conferences and seminars. He is an active Member of Various Professional Societies

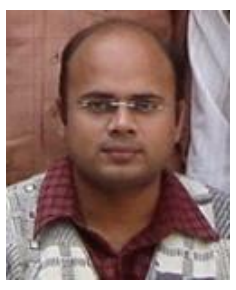
such as ISTE, IACSIT, IAENG etc. 